\title{
Study on the Legal Risk of Financial Products in Chinese Commercial Banking Industry
}

\author{
Zhou ALiu ${ }^{1, \text { a }}$ \\ ${ }^{1}$ Shijiazhuang vocational technology institute \\ Shijiazhuang 050081 \\ ae1091747341@qq.com
}

Keywords: Commercial Banking Industry, Financial Products, Legal Risk

\begin{abstract}
In recent years, with the sustained and rapid economic growth, the residents' income has been rapidly increasing, financial and investment will continue to enhance. Our financial market is a booming trend. However, compared with other mature market countries, the wealth management market in China started late, therelevant laws and regulations are lagging behind, investor self-protection awareness is relatively weak. Legal disputes on financial products occurred frequently, and these legal risks seriously hindered the healthy and rapid development of China'scapital market. Therefore the analysis of the legal risk of financial products is pretty necessary.
\end{abstract}

\section{Introduction}

In recent years, with the further development of financial markets, the development of China's commercial banks financial products very quickly, have a tremendous impact in social and economic life and investment market, while widespread concern of many investors, financial scholars and research institutions. Booming financial markets indicate that it meets investment needs at this stage the majority of investors, to broaden the investment channels for investors, on the other hand, the expansion of financial products market has also increased the intermediate business income of China's commercial banks, to help our country depth development of the capital market and money market. Although the financial products for financial market has a huge role in promoting, but due to financial products related laws and regulations are not perfect, personal finance product itself as well as the complexity of asymmetric information and other reasons, making the personal wealth management products have emerged a number of legal issues, which mainly including: legal relations parties to the transaction agreed not clear; commercial bank in financial product design, promotion and sales process for identifying legal risks, prevention capability is not strong; investors in the purchase of financial products one-sided focus on return on investment and risk prevention awareness is not strong, in the purchase of financial products is still with a lot of blindness. These problems are reflected in the practice of commercial banks is about personal finance products increased year by year controversy and dispute [1].

\section{The Meaning of Commercial Banking Financial Products}

"Commercial Bank Personal Financial Services Interim Measures," September 24, 2005 published in the Bank of personal financial services and professional services to clearly define the activities of asset management, investment advisory, financial planning and financial analysis for commercial banks to individuals, mainly for the commercial banks to use more of the unified management of investment funds, investors with financial products with the bank signed the agreement made some gains, and bear the risk. Commercial bank financial products is a similar collection of brokerage asset management plan Capital Trust scheme and securities investment fund financial products, commercial banks in the market potential target customers on the basis of systems analysis for a series of specific objectives customer base design with concurrency and selling a capital investment management solutions. According to different operating mechanism and management model, 
business financial products attributable to the commercial bank financing of integrated financial services business [2].

\section{The Species of Legal Risks of Commercial Banking Financial Products}

Commercial banking market access legal risks. With the growing capital markets and financial innovation, deepening the commercial financial products market is growing rapidly, the major commercial banks have begun to seize the market, issues related to this market access is particularly prominent. About financial products market access system mainly "commercial bank Personal Financial Services Interim Measures," promulgated by the CBRC, which states that the financial services market access system is divided into two categories - the approval system and reporting system. Approval system which mainly covers the financial guarantee business income or income properties with guaranteed financial products, financial services and other needs through the China Banking Regulatory Commission approved the business, such business must fulfill strict approval procedures; and reporting system is not CBRC required commercial banks to review and approval to the bank, but would like the local banking regulatory bureau reports. If the bank fails to clarify the nature itself of the sale of financial products, financial products failed to fulfill approval or reporting procedures, the program will result in deletion, if commercial banks and investors to legal dispute, the courts are likely because of the bank's procedures Absence The increase in the bank's civil liability.

Commercial bank charges compliance risk. From the business practices of commercial banks, the charges of financial products are mainly reflected in the following aspects: (1) the price of unreasonable fees that commercial banks in the sale of financial products charge high prices; (2) the fee is not enough transparency. When that is the commercial banks in the product specification and signed subscription contracts with investors, there are no clear standard management fees charged; (3) without the consent of the investors privately share return on investment. That commercial banks after receiving funds from investors and sign the relevant legal documents, it did not make clear arrangements for investment income, while higher if investment returns to investors, commercial banks will be privately retained part of the proceeds; and (4) commercial banks may exist in the case of illegal standard procedure when setting charges. In practice, the commercial banking business, because the credibility of financial products charge will lead to legal disputes banks caused great negative impact, therefore, the commercial banks in the costs of financial products must maintain sufficient vigilance [3].

Legal risk of financial products innovation. Due to the financial markets of recent years' trend of rapid development, making relevant laws and regulations lagged behind the pace of innovation of financial products, both of contradiction is very prominent, resulting in commercial banks are facing greater legal risk at the time of the conduct of financial product innovation. The nature of the business of financial products on a financial product, in the context of the ever-changing financial markets, innovation will become an inevitable requirement, and the current legislation in this area is relatively not perfect, in many cases the commercial banks have to take the form of walking a fine line of innovative financial products, so that commercial banks have been subject to punishment by the regulatory authorities. The above situation makes commercial banks lack a sound legal environment during external financial product innovation, the possibility of legal risks banks face increased.

\section{The Legal Risks Faced by Investors}

The legal risks in sales process. Due to the current sale of financial products and employees of many commercial banks and facing heavy sales task, therefore improper sales practices are common, such as overstated earnings, commitment preservation and false propaganda, to low investment risk tolerance who sells financial products such as high-risk. In many cases, the sales staff explains the risks to investors avoid financial products, but the focus of talk about high-yield investors are likely to get. For such cases, the "commercial bank Personal Financial Services Interim Measures," and a series of administrative regulations issued by the China Banking Regulatory Commission are to 
promote and sell financial products out of the detailed provisions, defined the responsibilities behavior of commercial banks, commercial banks if ignored these provisions should be held accountable and bear the corresponding legal consequences.

Asymmetric information risk. Information asymmetry has clearly reflected in the sales process of financial product. Secondly, the characteristics of financial products and make it certain risks. The presence of financial products and commodities huge difference, which for financial product issuers or salesperson leaves a potential space, they might take to pursue their own gain at the expense of the interests of investors, and investors through their difficult behavior effective prevention. This makes it very difficult for ordinary investors from financial products investment name to accurately grasp the subject matter. Investors after the signing of the contract, it is difficult to accurately informed of the whereabouts of investment funds, unable to learn the truth like financial products, it is difficult to make the right judgments on the quality of financial products or services. This makes the sales process investors' access to information obviously unfair and it is difficult to protect the fairness of the average investor's right to information and transactions. Visible, information asymmetry makes the extremely high cost of sales, in the case of lack of supervision, these costs primarily borne by consumers [4].

\section{The Policy and Recommendations to Prevent Legal Risks of Commercial Bank Financial Products}

Improve the legislative level of commercial banking financial products. At present, China's specialized law on regulating commercial bank financial products still exist to some extent on the absence of, firstly, the relatively low level of existing legislation. Secondly, and commercial financial products related legislation lag, prospective inadequate. Economic legislation should have certain forward-looking in order to meet the changing economic situation, but our legislation but is lagging behind in many cases are the development of a temporary provision in the event of problems before, so its legal effect is difficult to be assured. Although this innovative financial products business has been authorized by the CBRC, but legal up analysis, whether it meets the "Commercial Bank Law", the legislative spirit "Securities Act" and other higher-level laws are still open to question. In summary, the legal relationship between financial products into the "Commercial Bank Law" adjustment range exception urgent.

Make clear the nature of the legal relationship of commercial banking financial products. existing laws and regulations, the definition of the legal relationship between commercial bank financial products to investors and commercial banks in the principal - agent relationship can explain the problem more clearly, but also to finance problems civil liability of the parties concerned resolved products, but also for a clear legal relationship between the parties of the civil liability of the foundation. If this is categorized as a financial products division of a legal nature, so whether operating mode and investments funds raised legal compliance is also not self-evident that the relationship between commercial banks and investors is the principal - agent relationship, but the ownership of the funds raised still belong to investors, commercial banks only as operator of the funds to operate these funds, so for limiting the scope of the financial capital investment would be relatively small.

Strengthen the compliance management of commercial bank financial products staff conduct. As China's financial market in the ascendant, risk awareness staff some commercial financial products failed to keep pace with the times, knowledge of the relevant laws and regulations have not reached the standard required by the regulatory body. While sales of commercial banks to develop indicators also makes the staff in order to complete the heavy task and exaggerate gains conceal risks. Since the recommendation of both the staff of commercial banks financial products, the interpreter, it is also a direct participant contract entered into only by improving their understanding of the product promotional materials and the terms of the agreement, in order to give a reasonable explanation satisfied after investors found the 
problem. Thus commercial banks to improve understanding of risk awareness and sales personnel laws and regulations should invest heavily in training.

Fulfill disclosure obligations of financial products according to the law. Commercial banks should first clarify the exact point when selling financial products to investors at the same time, commercial banks must further explain financial products to investors by the use of investment tools and the mode of operation, indicating different market environments gains or losses under the situation changes, can not exaggerate or conceal the principal guarantee of financial products and benefits realization [5].

Design financial products rationally. Some commercial banks of our country financial products in the design process there are still some deficiencies in this area is mainly reflected in the legal status of financial products, legal relationship whether compliance with existing laws, regulations and national policies on. To avoid this risk, banks should design and the design process, as much as possible to avoid legal prohibitions, especially for non-guaranteed financial products design, should try to avoid legal risks that may occur in the financial innovation, and expand the premise of earnings .

Keep a rational view on financial products investment. For investors, risk prevention in order to improve their ability to invest in financial products, we must first learn to be more rational treatment of financial products and continuously improve risk awareness. Financial products as an investment product, its risks and benefits are coexisting, high returns must be accompanied by a high degree of risk, so investors and financial products when the temptation to be sure to see behind the risk that may arise.

Effectively improve their risk prevention ability. When selecting financial products, the vast majority of investors are one-sided focus on the yield financial products, while promotional materials and contracts risk provisions excluding skip. In particular, investors in the purchase of financial products, to obtain information related to the basic dependence on commercial banks' promotional materials and sales staff to explain their own lack of investor risk identification and prevention. Therefore, investors should carefully read the text of the contract should be in terms of the types of risks when choosing commercial bank financial products, financial products can be aware of the risks incurred.

\section{Conclusion}

In the present case, there is a big flaw of the legal regulation of commercial banks financial products. There is some missing either on regulatory or protection of the rights of investors. China should focus on the characteristics and circumstances of financial market development, unified adaptability to make changes from the legislative, regulatory and legal system.

\section{References}

[1] B. N. Ma, The legal problems of commercial bank financial products, J. Modern Law. 44 (2010) 146-147.

[2] H.X.Zeng, The risk analysis of commercial bank personal finance market, J. Legal Science. 18(2005) 55-57.

[3] J.H.Xue, The nature and regulatory of commercial bank financing business, J. Contemporary Economic, 32(2012) 189-190.

[4] Y.J.Qi, The review and consideration of bank supervision law system, J, Modern Finance, $4(2007) 38-40$.

[5] Y.M.Tian, The commercial bank private financing business and its legal risk control, J. Modern Finance, 9(2013) 142-150. 